\title{
Farklı Geçmiş Yaşantılardan Gelen Çocukların Mutluluk ve Gelecek ile İlgili Görüşleri
}

\section{Happiness and Future Views of Children Coming from Different Backgrounds}

\author{
Şakire OCAK KARABAY, Ege Üniversitesi Eğitim Fakültesi, sakire.ocak@ege.edu.tr \\ Damla GÜZELDERE AYDIN, Pamukkale Üniversitesi Eğitim Fakültesi, damlaguzeldere@hotmail.com
}

\begin{abstract}
ÖZ. Araştırmanın amacı, sokakta çalışan çocuklar ile farklı ekonomik düzeye (orta ve yüksek) sahip çocukların kendi duygu durumlarına, yaşamlarına ve geleceğe dair bakış açılarını belirlemek ve öğretmen adaylarının araştırma sürecinde sokakta çalışan çocuklara ilişsin düşüncelerini incelemektir. Araştırmada betimsel tarama yöntemi kullanılmıştır. Çalışma grubunu, 9-15 yaş aralığında toplam 70 çocuk ve 6 öğretmen adayı olușturmuștur. Veriler, görüşme tekniği kullanılarak elde edilmiş ve verilerin analizinde betimsel analiz kullanılmıştır. Çalışma sonucunda, her iki çocuk grubunun da eğlenceli etkinlikler yapmayı, hediye/refah içerisinde olmayı mutluluk kaynağı olarak ifade ettikleri görülmüştür. Sokakta çalışan çocukların okula gitme isteklerini diğer gruptaki çocuklara nazaran daha çok dile getirdikleri tespit edilmiștir. Bir bașka farklılık olarak farklı ekonomik düzeye sahip çocukların sokakta çalıșan çocuklara nazaran yeteneklerinin daha çok farkında oldukları ve bunları daha çok dile getirdikleri görülmüştür. Ayrıca öğretmen adaylarından edinilen bulgular incelendiğinde, çalışmaya başlamadan önce sokakta çalışan çocuklara yönelik önyargıları, korkuları olduğu ancak çalışma sonunda çocukların yaklaşımları ile bu önyargı ve korkulardan uzaklaştıkları görülmüştür.
\end{abstract}

Anahtar Sözcükler: Sokak Çocukları, Sokakta Çalışan Çocuklar, Çocuk Hakları

\begin{abstract}
The purpose of the research is to define viewpoints towards future, lives ad emotional situations of the children having different economical level and working at streets and to study the notions regarding children working at street of the preservive teacher. In the research descriptive method was used. Working group consisted of 70 children at the ages of 9 to 15 and 6 preservice teacher. Data was gathered by using interview technique and descriptive analysis was used while analyzing data. At the end of research, both children groups stated that doing entertaining activities, receiving presents, being at prosperity are sources of happiness. Children working at street stated the request to study in a school more than the other group. Another difference is that children at different economical levels compared with the children working at streets are more aware of their abilities. Moreover preservice teachers had fears and prejudice before they started working with the children at streets but they overcome these prejudice and fears during study.
\end{abstract}

Keywords. Street Children, Children Working at Street, Child Rights

\section{SUMMARY}

Purpose and Significance: Generally speaking, the researches regarding these children are to detect the situation and the researches regarding studying the relationship with some psychological variables of working at streets are rarely. The purpose of this study is define the viewpoints towards future, their lives, their own emotional situations of the children having different economical levels and working at streets and to study the preservice teachers' thoughts during the research and related to the children working at streets. In this regard, this research will contribute to data accumulation in this field and the results will be informative not only for institution but for families as well.

Methodology: The number of participant were 70 children and 6 preservice teacher. Descriptive scanning method was used while analyzing the data gathered by way of interview technique.

Results: When the data gathered from the children was analyzed, it was noticed that both the children working at street and the children in the other group expresed that amusing activities are the source of happiness. When asked what would make them happy, both groups stated that they expect present. While the children working at street expressed their ordinary expectations and wishes such as "if only I have a private room" or "I wish I have a bed", the other group stated their luxurious expectations and wishes such as "If I have a real race car" or "I wish I have a auto showroom". It was determined that the children at street miss the school life and want to attend a school and to study their lessons. Thus, the children working at street compared to the children in the other group expressed more their wishes about taking training. The children at higher 
economical level have several hobbies, think that they are talented in many more fields, but the children working at street had no activities to be called hobbies and they are less aware of their abilities. Preservice teachers expressed that they had prejudices and fears against the children working at street but after interacting with them during the study they overcame these fears and prejudices.

Discussion and Conclusion: The children working at street expressed their wishes and expectations such as education, good living conditions, the cicumstances in which they can improve themselves without any previligies. After the preservice teachers performed interviews with the children working at street, they changed their perspectives on these children. In this direction, first of all, it is necessary to be aware of the children working at street, to understand their necesities and to be sensitive to find solutions. Furthermore, it is suggested that the awareness of the society about these children has to be raised, prejudice against these children is to be neutralized, works to improve the live conditions of these children are to be done.

\section{GíRiş}

Günümüzde, özellikle de büyük şehirlerde, sokakta çalışan çocuk sayısının oldukça fazla olduğu belirtilmektedir. Son yıllarda tüm dünyada özellikle de gelișmekte olan ülkelerde hızlı değişimler ekonomik siyasal ve politik faktörler sokak çocuklarının hızla artmasına neden olmuş ve günümüz dünyasının en önemli problemleri arasında yerini almaya başlamıştır (Arnas, 2003; Konanç 1992). Kırsal alanlardan göç, hızlı kentleşme, kontrol edilemeyen nüfus artışı ve gelir dağılımındaki eșitsizlikler bu sorunun en temel nedenleri arasında yer almaktadır. Yoğun göçler nedeni ile büyük iller yığınlar halinde göç almaktadır ve kentlere tamamen hazırlıksız biçimde göç eden bu ailelerin çocukları, aile bütçesine katkıda bulunabilmek zorunda kalmakta ve kendilerini sokaklarda korunmasız koşullar altında çalışırken bulmaktadırlar (Alparslan, 2012).

Türkiye'de ve dünyada bu çocukların ağır tehlikeli ve istismara açık şartlarda çalışmaları ve yaşamaları çoğu zaman eğitimden yoksun kalmalarına yol açmakla birlikte onarılması güç sorunlara neden olmaktadır. Sorunları çözmenin ilk adımının ise bu çocukları ve sorunlarını, bütünüyle tanımak olduğu ifade edilmektir (Şişman, 2006). Sağlıssız aile içinde büyümenin getirdiği handikaplar ile birlikte yaşına uygun olmayan bir iş ortamının içinde aile bütçesine katkıda bulunması beklenmekte olan çok sayıda çocuk sokaklarda, ovalarda, çeşitli yerlerde çalışırken bazı ihmal ve istismar türlerine maruz kalmaktadır. Bu çocukların hem ruhsal hem de fiziksel sağlığı tehlikeye sokulmaktadır (Yıldız, 2007; Yürük ve Yalçın, 2008). Bu noktada dikkate almamız gereken sorun pek çok çocuğun doğuştan sahip olduğu potansiyel kapasitesini tam olarak gerçekleştiremeyeceği uygun olmayan ortamlarda büyümek zorunda bırakılmış olmasıdır (Kağıtçıbaşı, 2012). Çocukların kendini ait, güvende hissettikleri ve sevildikleri zengin bir sosyal çevrenin en çok ihtiyaç duydukları unsur olduğu belirtilmektedir (Perry ve Szalavitz, 2014). Yetişkinler olarak ilk görevimiz çocukların yaşamını korumaktır. Her çocuğun ailesinden yoksun kaldığında ya da aile ortamı onun için uygun olmadığında devletten özel koruma ve yardım alma hakkı olduğu çocuk hakları sözleşmesinde yer almaktadır (UNICEF, 2004). Özellikle erken yaşlarda çocukların beslenme, sevgi ve barınma gibi güvenli ortamda yaşama ihtiyaçlarının eksiksiz karşılanması gerektiği birçok araştırmacı tarafından vurgulanmaktadır. Gelişim ve eğitim eksikliğinin çok sayıda çocuğu olumsuz etkilemesini engellemek için gayret göstermemenin insan haklarını ihlal etmek anlamına geldiği belirtilmektedir (Kağıtçıbaşı, 2012).

Genellikle, bu çocuklarla ilişkili gerçekleştirilen araștırmaların durumu saptamaya yönelik olduğu (Güngör, 2008; Yetim ve Çağlayandereli, 2007; Bilgin, 2012; Tor, 2010; Alparslan ve Karaoğlan, 2012) gözlenmektedir. Dolayısıyla bu çocukların yaşadıkları sıkıntıları ve bu sıkıntıların neden olduğu olumsuz duygusal yaşantıları ortaya çıkaracak derinlemesine araştırmalar yapılmasına gereksinim duyulmaktadır. $\mathrm{Bu}$ çocukların zor yaşam deneyimlerinin onların duygularını, insanlarla olan ilişkilerini, geleceğe dair bakış açılarını nasıl etkilediğini ortaya çıkarmak, gerekli desteklerin sunulmasında yol gösterici olacaktır. Ayrıca sokakta çalışan çocukların sokağa ilişkin algılarına dair yapılmış olan araștırmaların yok denecek kadar az olması dolayısıyla bu çocukların kendi gerçeklerine ilişkin bakış açllarına dair bilgilerde kıymetli olacaktır (Bademci, 2013). 
Sokakta çalışan çocukların yaşantılarındaki zorlukların ve travmaların yaşıtlarına göre olumsuz duygu durumlarına daha fazla yol açacağı, yaşamlarına ve geleceğe dair bakış açılarında umutsuzluk ve kaygının daha yüksek olacağı düşünülmektedir. Nitekim Şimşek ve Erol (2003) çalışmalarında çalışan çocukların davranışsal ve duygusal sorunlarının çalışmayan çocuklardan daha fazla olduğunu ortaya koymuşlardır. Araştırmacılara göre, araştırmada elde edilen bulgular çalıșan çocukların toplumsal ruh sağlığı politikaları açısından önemsenmesi gereken bir risk grubu olduğunu düşündürmektedir. Sokakta çalışan çocukların depresif belirtileri ve depresyon puanı ortalamasının okula devam eden çocukların ortalamasından anlamlı olarak daha yüksek bulunması (Aysev, Ulukol ve Ceyhun, 2000) bu duruma bir örnek olarak verilebilir. Bir diğer araştırma bulgusuna göre ise sokakta çalışan çocuklar, sokakta çalışmayan çocuklara göre daha saldırgan davranışlar göstermektedir (Erdoğdu ve Oto, 2004). Araştırmacılar temel gereksinimlerin karşılanmasında doğal çevrenin yaşamsal önemine dikkat çekmektedirler, özellikle sosyal çevrenin bireyin kendine özgü ruhsal yönden sağlıklı bir kişilik geliştirmesinde önemli etkiye sahip olduğunu vurgulamaktadırlar. Çocukların \%24,7 'si aile bireylerinden biri ya da birileri tarafından fiziksel, duygusal ve cinsel olmak üzere istismara uğratıldıkları. (Esenay, Öncü, Kurt ve Özey, 2012) ve bu çocukların giderek suç eğilimli hale geldikleri yönünde bulgular da (Bilgin, 2009) saptanmıştır. Ancak alan yazınında sokakta çalıştırılan çocukların benlik saygısı denetim odağı ve umutsuzluk düzeyleri açısından puan ortalamaları arasında fark olmakla birlikte bu farklılıkların anlamlı sayılabilecek düzeyde yüksek olmadığını saptayan çalışma bulguları da mevcuttur (Başal, Derman ve Peymi, 2010).

Araştırma sonuçları değerlendirildiğinde sokağın çocuklara getirdiği dezavantajlar hakkında farklı görüşler bulunmaktadır dolayısıyla sokakta çalışıyor olmanın bazı psikolojik değişkenlerle ilişkisini saptamaya yönelik derinlemesine araștırmaların arttırılmasına gereksinim duyulmaktadır. $\mathrm{Bu}$ bakımdan bu araștırmanın, ülkemizde bu alanda ki bilgi birikimine katkıda bulunabileceği ve sonuçların kurum ve aileler için bilgi verici olacağı düșünülmektedir. Ayrıca çalıșmada öğretmen adaylarının sokakta çalışan çocuklarla yaptıkları görüşmelerde bu çocukların mutlu oldukları șeylerin, gelecekle ilgili beklentilerinin ve hayallerinin neler olduğunu duymaları onlarda nasıl bir etkiye yol açtığı da araştırılmıştır. Çalışmanın bu boyutundan elde edilen bulguların sokakta çalışan çocuklara karşı geliştirilmiş olan ön yargıları azaltabileceği düşünülmektedir. Bu doğrultuda araştırmada aşağıdaki sorulara yanıt aranmıștır:

1. Sokakta çalışan çocukların farklı ekonomik düzeye (orta ve yüksek) sahip olan yaşıtlarıyla, duygu durumları, yaşamlarına yönelik bakış açıları ve gelecek planları arasında nasıl bir fark vardır?

2. Okulöncesi öğretmenliği anabilim dalında okuyan öğretmen adaylarının sokakta çalışan çocuklarla kurdukları etkileşimler ile ilgili düşünceleri nelerdir?

\section{YÖNTEM}

\section{Araștırmanın Deseni}

Çalışmada öncelikle sokakta çalışan ve farklı ekonomik düzeye (orta ve yüksek) sahip olan çocukların kendi duygu durumlarına, yaşamlarına ve geleceğe dair bakış açılarını belirlemek ve okul öncesi öğretmenliği anabilim dalında okuyan son sınıf öğretmen adaylarının araștırma sürecinde sokakta çalışan çocuklara ilişkin düşüncelerini betimlemek amacıyla tarama araştırmasına başvurulmuştur. Tarama araştırması bireylerle anket doldurulan veya tutumları, faaliyetleri, herhangi konulardaki düşünceleri ile ilgili görüşme yapılan bir araştırma yöntemi olarak açılanmaktadır (Christensen, Johnson ve Turner, 2015).

\section{Çalışma Grubu}

Araștırma amacı doğrultusunda İzmir ve Manisa ilinde yaşamakta olan 9-15 yaș aralığında toplam 70 çocuk (35'i sokakta çalışan ve 35'i farklı ekonomik düzeye sahip olan çocuk) çalışma grubunu oluşturmuştur. Ayrıca Ege Üniversitesi'nde okul öncesi öğretmenliği anabilim dalında okuyan son sınıf öğrencisi olan 6 öğretmen adayı çalışmada yer almıştır. Araştırma Projesi dersi kapsamında 12 öğrenci tesadüfü olarak seçilmiştir. Bu 12 öğrenciye araştırmacılar tarafından çalışmak istedikleri konuları belirlemeleri için bir hafta süre tanınmıştır. Araştırma projesinde yer 
alan 6 öğrenci sokakta çalışan çocuklar hakkında araştırma yapmak istediklerini belirtmişlerdir. Böylelikle çalışmada hem katılımcı olarak hem de verilerin toplanması aşamasında yer almışlardır.

\section{Veri Toplama Araçları}

Çalışmada veri toplama aracı olarak "Sokakta Çalışan ve Çalışmayan Çocukların Yaşamlarına Dair Bakış Açılarını Değerlendirme Formu " ve "Sokakta Çalışan Çocuklara Yönelik Öğretmen Adaylarının Düşüncelerini İnceleme Formu" olarak iki form kullanılmıştır. "Sokakta Çalışan ve Çalışmayan Çocukların Yaşamlarına Dair Bakış Açılarını Değerlendirme Formu" için görünüş geçerliliği yapılmıştır. Bu kapsamda formun, testin amacı ve kapsamı hakkında bilgi verici olduğu uzmanlardan alınan geri dönütlerle belirlenmiştir. Araştırmada araştırmacılar tarafından ilgili literatür taranarak konuyla ilişkili taslak sorular oluşturulmuş söz konusu görüşme formu iki uzman tarafından değerlendirilmiş gerekli değişiklikler yapıldıktan sonra ön uygulama formu çocuklarla pilot uygulamalar gerçekleştirilerek sınanmıştır. Pilot uygulamalarda 12 çocuk yer almış soruların anlaşılır bulunduğu görüşmelerde sıkıntı yaşanmadığı gözlenmiștir. Bu form sokakta çalışan ve çalışmayan çocukların mutluluk eşikleri, kendilerine, yaşamlarına ve geleceğe dair bakış açıları ve meslek seçimleri hakkındaki düşüncelerini incelemek amacıyla oluşturulmuş bir formdur. Formun birinci kısmı çocukların yaşı, cinsiyet, eğitim durumu vb. genel bilgileri kapsamaktadır. İkinci kısmında ise onları mutlu eden durumları, hayatlarında sahip oldukları en güzel kişi/nesneleri, kendilerinde en beğendikleri ve yetenekli hissettikleri özellikleri, gelecekle ilgili planları, yaşamlarındaki en büyük destekçilerini, günlük yaşamlarında en çok ne yapmak istediklerini araştıran sorulara yer verilmiştir. "Sokakta Çalışan Çocuklara Yönelik Öğretmen Adaylarının Düșüncelerini İnceleme Formu" araștırmacı tarafından oluşturulmuştur ve uzmanlar tarafından görünüş geçerliliği yapılmış gerekli düzenlemeler gerçekleștirilmiştir. Formda üç boyut hakkında düşüncelerin toplanması hedeflenmiştir; bu boyutlar öğretmen adaylarının veri toplama öncesi çocuklara yönelik düşüncelerini, veri toplama sürecindeki duygularını ve karşılaştıkları zorlukları ve gelecekte söz konusu çocuklarla ilişkili nasıl araştırmalara gereksinim duyulduğunu kapsayan sorular içermektedir.

Çalışmada bir araştırma konusu ya da bir soru hakkında derinlemesine bilgiler elde edilmesine olanak sağlayan (Büyüköztürk, Çakmak, Akgün, Karadeniz ve Demirel, 2011) görüşme tekniği kullanılmıştır. Sokakta çalışan çocuklar ve orta-yüksek sosyo-ekonomik seviyede aile yaşantısına sahip çocuklarla yapılan bireysel görüşmelerde birden fazla görüşmeci yer aldığı için ve görüşmeci yanlılığını azaltmak amacıyla (Yıldırım ve Şimşek, 2013) görüşme tekniği türlerinden standartlaştırılmış açık uçlu görüşme kullanılmıştır. Ayrıca öğretmen adaylarıyla özellikle sokakta çalışan çocuklarla yapılacak görüşmelerin başarılı olabilmesi için görüşmeler sırasında nelere dikkat etmeleri gerektiği konusunda bilgilendirmelerde bulunulmuş ortaya çıkabilecek zorluklar karşısında neler yapabilecekleri tartışılmıştır. Öğretmen adayları çalışmada veri toplama sürecinde görev almakla birlikte aynı zamanda katılımcı olarak çalışmada yer alarak görüşmeler yapılmış form doldurulmuştur.

\section{Veri Toplama Süreci}

Gönüllülük esasına dayalı olarak seçilen çocuklarla bireysel görüşmeler gerçekleştirilmiş, isimleri sorulmamıştır. Araştırmaya katılan çocuklara verdikleri cevaplar hakkında hiçbir yorum yapılmamasına dikkat edilerek soruları rahatça cevaplamalarına olanak sağlanmış ve çocukların verdiği yanıtlar düzeltilmeden, ağızlarından çıktığı şekliyle kaydedilmiştir. Sokakta çalışan çocuklarla yapılan görüşmeler, onların çalışma ortamlarında 15-20 dakika sürmüş ve genellikle yoğun ve işlek caddelerde gerçekleştirilmiştir. Toplamda 46 sokakta çalışan çocuğa bireysel görüşme talebinde bulunulmasına rağmen görüşmeyi gönüllü olarak gerçekleştirmek istemeyen ya da görüşmeyi sürdüremeyen sokakta çalışan 11 çocuk çalışmaya dahil edilmemiş 35 çocuk ile görüşmeler gerçekleştirilebilmiştir. Farklı ekonomik düzeye sahip olan 35 çocuk ile görüşmeler ise okul içinde veya sakin bir mekânda yapılmıştır.

Ege Üniversitesi'nde okul öncesi öğretmenliği anabilim dalında okuyan son sınıf öğrencisi olan 6 öğretmen adayına genel bilgilendirme yapılmış ve 'Sokakta Çalışan Çocuklara Yönelik Öğretmen Adaylarının Düşüncelerini İnceleme Formu' verilerek bir ön görüşme gerçekleştirilmiştir. İkinci 
görüşmede adayların yanıtları uzman tarafından tek tek sondalanarak derinlemesine bilgiye ulaşılmaya çalışılmıştır. Her bir görüşme yaklaşık bir buçuk saat sürmüştür.

\section{Verilerin Analizi}

"Sokakta Çalışan ve Çalışmayan Çocukların Kendi Yaşamlarına Dair Bakış Açılarını Değerlendirme Formu "ve "Sokakta Çalışan Çocuklara Yönelik Öğretmen Adaylarının Düşüncelerini İnceleme Formu" kullanılarak elde edilen verilerin analizinde betimsel analiz kullanılmıștır. Betimsel analizde amaç, araştırmada elde edilen bulguları düzgün, anlaşılır ve yorumlanmış şekilde okuyucuya aktarmaktır (Yıldırım ve Şimşek, 2013). Bu süreçte kavramsal çerçeve oluşturulması, oluşturulan çerçeveye göre verilerin işlenmesi, bulguların tanımlanması ve yorumlanması olan betimsel analiz aşamaları (Yıldırım ve Şimşek, 2013) izlenmiştir. Analiz süresince konu ile ilgili yapılan çalışmalar araştırılmış, kullanılan temalar değerlendirilmiştir. Bu doğrultuda, çalışmada elde edilen veriler her bir soru için ayrı ayrı listelenmiştir. Ardından her sorunun içeriği analiz edilmiş ve kendi içerisinde temalar doğrultusunda kategorilere ve alt dallara ayrılmıştır. Veriler ve araştırmacılar tarafından oluşturulan kategori alt dalları, iki uzmandan ve literatürden destek alınarak organize edilmiș, düzeltmeler yapılmıș ve kategoriler üzerinde fikir birliğine varılmıștır. Bu aşamanın ardından veriler tekrar okunarak belirlenen kategori ve alt kategorilere göre kodlanmıştır. Ayrıca alandan bir uzmanın tutarlılık incelemesine tabii tutulmuştur ve oluşturulan temaların içeriğe uygunluğu için onay alınmıştır, tutarlılık düzeyi tespit edilmeye çalışılmış ve yapılan güvenirlik analizi sonucunda (Güvenirlik=görüş birliği/görüş birliği+ görüş ayrılığı)X100) .84 oranında bir tutarlılık olduğu saptanmıștır. Bulgular kısmında öğretmen adaylarının görüşlerine ilişkin direk alıntılara yer verilmiştir. Etik sorunları önlemek amacı ile öğretmen adaylarının kimlik bilgileri açık olarak verilmemiş K1, K2, K3, ... K6 olarak kodlanmıştır.

\section{BULGULAR}

$\mathrm{Bu}$ bölümde "Sokakta Çalıșan ve Çalıșmayan Çocukların Yaşamlarına Dair Bakış Açılarını Değerlendirme Formu" nda toplanan verilerden elde edilen bulgular yer almaktadır. Görüşmeler sonucunda elde edilen bulgular formda yer alan sorulara göre sıralanarak verilmiştir.

Tablo 1. Şu zamana kadar yaşamında seni en çok mutlu eden 3 olay/durum nedir? Sorusuna verilen cevapların dağılımı

\begin{tabular}{lcc}
\hline Kategoriler & Sokakta çalışan çocuklar & $\begin{array}{c}\text { Farklı Ekonomik Düzeye Sahip } \\
\text { Çocuklar }\end{array}$ \\
& f & f \\
\hline Eğlenceli etkinlikler & 18 & 30 \\
Aile & 17 & 25 \\
Hediye & 10 & 18 \\
Eğitim & 4 & 11 \\
Sevgili & 4 & 1 \\
Maddi kazanç & 4 & - \\
Mutlu anı yok & 5 & - \\
\hline
\end{tabular}

Şu zamana kadar yaşamında seni en çok mutlu eden 3 olay/durum nedir? Sorusuna verilen cevaplar incelendiğinde hem sokakta çalışan çocuklar için hem de diğer çocuk grubu için oyun oynamak, gezmeye gitmek, aktiviteler yapmak ve özel günlerin kutlanması gibi eğlenceli etkinliklerin en mutluluk veren unsur olduğu saptanmıştır. Her iki çocuk grubu da aile ile vakit geçirme, yeni bir kardeşin doğması, yeni bir eve taşınmak gibi aile 'ye yönelik mutluluklarını dile getirirken sokakta çalışan çocuklar aile içi sorunlarının çözüldüğünü ve bundan dolayı mutlu olduklarını da ifade etmişlerdir. Sokakta çalışan çocuklar ve diğer gruptaki çocuklar onlara oyuncak, elektronik aletler gibi hediye verilmesinden mutluluk duydukların belirtmişlerdir. Eğitim kategorisinde her iki çocuk grubu da okula gitmekten mutlu olduklarını ifade ederken orta ve yüksek sosyo-ekonomik seviyede aile yaşantısına sahip çocuklar okul başarılarına yönelik mutluluklarını da dile getirmişlerdir. Bunlarla beraber sokakta çalışan çocuklar çoğunluk olmakla birlikte her iki gruptan çocuklar sevgili 'ye sahip olmaktan mutlu olduklarını ifade etmişlerdir. Ayrıca sadece sokakta çalışan çocuklar tarafından maddi kazanç kategorisinde para kazanmak mutluluk kaynağı olarak belirtilmiştir. 
Çalışmanın yine dikkat çekici bir bulgusu ise sokakta çalışan beş çocuğun mutluluk algısına yönelik farklı bir bakıșa sahip olmalarıdır. Bu çocuklar bu zamana kadar yaşamlarında hiç mutlu olmadıklarını dile getirmekle birlikte biri düştügünde ya da kavga edenleri izlediklerinde mutlu olduklarını açıklamışlardır.

Tablo 2. Yaşamında bundan sonra ne olursa çok mutlu olursun? Sorusuna verilen cevapların dağılımı

\begin{tabular}{lcc}
\hline Kategoriler & Sokakta çalışan çocuklar & $\begin{array}{c}\text { Farklı Ekonomik Düzeye Sahip } \\
\text { Çocuklar } \\
\text { f }\end{array}$ \\
\hline Hediye/refah beklentisi & f & 10 \\
Eğitim & 7 & 12 \\
Aile & 7 & 7 \\
Eğlenceli etkinlikler & 3 & 3 \\
Meslek & 2 & - \\
Sevgili & 4 & 6 \\
\hline
\end{tabular}

Yaşamında bundan sonra ne olursa çok mutlu olursun? Sorusuna verilen cevaplar incelendiğinde her iki çocuk grubunun da hediye refah beklentisi içerisinde oldukları saptanmıștır. Ayrıca çalışmada sokakta çalıșan çocukların mutluluk kaynağının hediye ve refah beklentisi yönünde daha yüksek olması da çalıșmada beklenen bir bulgu olarak görülmektedir. Söz konusu isteklerin ve beklentilerin içeriğine bakıldığında sokakta çalışan çocuklar "kendime ait bir odam olursa, yatağım olursa, uçurtmam olursa" gibi olağan beklenti ve isteklere yönelik yanıtlar verirken farklı ekonomik düzeye sahip çocukların "gerçek yarış arabam olursa, araba galerim olursa, bana daha büyük sürprizler yapılırsa" gibi lüks isteklerinin olduğu saptanmıştır. Eğitim kategorisi incelendiğinde sokakta çalışan çocuklar sadece okula gidip, çalışmazsam mutlu olurum yanıtlarını verirken, diğer çocuk grubu okulda başarılı olmak, başarı belgeleri almak gibi yanıtlarda bulunmuşlardır. Aile kategorisi içerisinde yer alan bulgulara bakıldığında sokakta çalışan çocukların "babam hapisten çıkarsa mutlu olurum", "Annem ile babam iyi olurlarsa mutlu olurum" gibi aile içi sorunların çözülmesine yönelik isteklerinin olduğu saptanırken diğer grubun aileleriyle daha fazla vakit geçirmeye yönelik istekleri dikkat çekmektedir. Bunlarla birlikte her iki çocuk grubu da oyun oynamak, gezmeye gitmek gibi eğlenceli etkinlikler yaparlarsa, istedikleri mesleklere sahip olurlarsa mutlu olacaklarını ifade etmişlerdir. Ayrıca sevgili kategorisinin altında sokakta çalışan kız çocuklarından bazıları beni istemeye gelirlerse, bir sevgiliye sahip olursam mutlu olacağım gibi yanıtlar vermişlerdir.

Tablo 3. Eğer çalışmasaydın/okula gitmeseydin günlük yaşamında en çok ne yapmak isterdin? Sorusuna verilen cevapların dağılımı

\begin{tabular}{lcc}
\hline Kategoriler & Sokakta çalışan çocuklar & $\begin{array}{c}\text { Farklı Ekonomik Düzeye Sahip } \\
\text { Çocuklar }\end{array}$ \\
& $\mathrm{f}$ & $\mathrm{f}$ \\
\hline Eğlenceli etkinlikler & 26 & 34 \\
Eğitim & 11 & 3 \\
Ev işleri & 5 & 1 \\
İş hayatı & 3 & 4 \\
Dinlenme & 3 & 4 \\
\hline
\end{tabular}

Eğer çalışmasaydın günlük yaşamında en çok ne yapmak isterdin? Sorusuna verilen cevaplar incelendiğinde her iki çocuk grubu da en çok oyun oynamak, gezmek, bilgisayar tablet kullanmak, bisiklet sürmek gibi eğlenceli etkinlikler yapmaya yönelik istediklerini dile getirirken farklı ekonomik düzeye sahip çocuklardan bazıları kitap okuma, müzik dinleme, dans kursuna gitme gibi aktiviteler yapmak istediklerini de ifade etmişlerdir. Sokakta çalışan çocukların yaşam koşulları bu türden aktiviteleri desteklemekte imkân sağlamadığı için sokakta çalışan çocuk grubunda bu bulguya rastlanmamıştır. Eğitim kategorisi altında sokakta çalışan çocuklar okula gitme isteklerini, ders çalışma isteklerini diğer gruptaki çocuklara nazaran daha çok dile getirmişlerdir. Bu çocukların çalıştıkları için okula gidemediklerini, okula gidenlerin de işlerinden dolayı derslerine çalışamadıklarını ve bu yüzden çalışmayıp sadece okula gitmek istediklerini ifade ettikleri görülmüştür. Ev İşleri kategorisi altında her iki gruptaki çocuklar da, annelerine yardım etmek 
istediklerini ifade etmişlerdir. Sokakta çalışan çocukların ev işleri yaparak annelerine yardım etme isteklerinin daha çok olması, bu çocukların küçük yaşlardan itibaren sorumluluk almaya başlamaları ile açıklanabilir. Iş̧ Hayatı kategorisi altında sokakta çalışan çocuklar düzgün bir işte çalışma isteklerini dile getirirken; farklı ekonomik düzeye sahip çocuklar kitapçı açmak, garsonluk yapmak, pastanede çalışmak gibi isteklerini dile getirmişlerdir. Ayrıca her iki çocuk grubu da Dinlenme kategorisi altında evde oturarak dinlenmek istediklerini ifade etmişlerdir.

Tablo 4. Yaşamında sahip olduğunu düşündüğün en değerli kişi/nesne kimdir/nedir? Yaşamında en büyük desteği nereden veya kimden alıyorsun? Sorusuna verilen cevapların dağılımı

\begin{tabular}{lcc}
\hline Kategoriler & Sokakta çalışan çocuklar & $\begin{array}{c}\text { Farklı Ekonomik Düzeye Sahip } \\
\text { Çocuklar } \\
\end{array}$ \\
& $\mathrm{f}$ & $\mathrm{f}$ \\
\hline Kişiler & 47 & 55 \\
Nesneler & 3 & 6 \\
\hline
\end{tabular}

Yaşamında sahip olduğunu düşündüğün en değerli kişi/nesne kimdir/nedir? Yaşamında en büyük desteği nereden veya kimden alıyorsun? Sorusuna verilen cevaplar incelendiğinde her iki gruptaki çocukların yaşamında sahip olduğunu düşündüğü en değerli kişinin ve onlara en çok destek veren kişinin anneleri olduğu saptanmıştır. Annelerini takiben babalarının, kardeşlerinin, akrabalarının onlar için değerli ve destekçi olduklarını ifade etmişlerdir. Bununla birlikte sokakta çalışan çocuklardan bazıları oyuncak arabasının, elbisesinin ve güllerinin (sattığı nesne) değerli olduğunu söylerken; farklı ekonomik düzeye sahip olan bazı çocuklar okul çantası, uğurlu kalemi, futbol topu gibi nesnelerin kendileri için değerli olduğunu belirtmişlerdir. Bu bulgulara ek olarak sokakta çalışan bir çocuğun kimseden destek almadığı saptanmıștır.

Tablo 5. Kendinde beğendiğin yetenekli hissettiğin en güzel özellik nedir? Sorusuna verilen cevapların dağılımı

\begin{tabular}{lcc}
\hline Kategoriler & Sokakta çalışan çocuklar & $\begin{array}{c}\text { Farklı Ekonomik Düzeye Sahip } \\
\text { Çocuklar }\end{array}$ \\
& $\mathrm{f}$ & $\mathrm{f}$ \\
\hline Aktivite & 28 & 50 \\
Fiziksel görünüş & 8 & 2 \\
Eğitim & 4 & 5 \\
İletişim becerileri & 1 & 5 \\
\hline
\end{tabular}

Kendinde beğendiğin yetenekli hissettiğin en güzel özellik nedir? Sorusuna verilen yanıtlar söylenme sıklı̆̆ına göre incelendiğinde her iki çocuk gurubu da basket, futbol gibi spor dallarında yetenekli olduklarını, aktivitelere yönelik yeteneklerinin olduğunu ifade etmişlerdir. Bununla birlikte fiziksel görünüşlerine (saç, göz vb.) yönelik beğenilerini dile getirirken; eğitim kategorisi altında okul başarılarını da ifade etmişlerdir. Her iki çocuk grubunun da kendilerinde beğendikleri yetenekli hissettikleri bir diğer özelliğin iletişim becerileri olduğu saptanmıştır. Bu kapsamda sosyal ve girişken olduklarını ifade etmişlerdir. Bu bulgular dışında, sokakta çalışan iki çocuk yeteneklerinin olmadığını ifade ederken genel olarak farklı ekonomik düzeye sahip olan çocukların sokakta çalışan çocuklara nazaran yeteneklerinin daha çok farkında oldukları ve bunları daha çok dile getirdikleri görülmüştür.

Tablo 6. Gelecek ile ilgili planların nelerdir? İleride ne olmak istiyorsun? Sorusuna verilen cevapların dağılımı

\begin{tabular}{lcc}
\hline Kategoriler & Sokakta Çalışan Çocuklar & $\begin{array}{c}\text { Farklı Ekonomik Düzeye Sahip } \\
\text { Çocuklar }\end{array}$ \\
& $\mathrm{f}$ & $\mathrm{f}$ \\
\hline Meslek & 34 & 42 \\
\hline
\end{tabular}

Gelecek ile ilgili planların nelerdir? İleride ne olmak istiyorsun? Sorusuna karşıllı çocukların ilk akıllarına gelen mesleğe yönelik tercihleri olmuştur. Sokakta çalışan çocuklar sırasıyla öğretmen (f:8), doktor (f:6), polis (f:4), hemşire (f:3), pilot (f:2), sporcu (f:2), asker (f:2), mühendis (f:1), şarkıcı (f:1), iş adamı (f:1), serbest meslek (f:1), araba tamircisi (f:1), geri dönüșüm iși (f:1), 
ev hanımı (f:1) olmak istediklerini ifade ederken; farklı ekonomik düzeye sahip olan çocuklar sirasıyla doktor (f:8), öğretmen (f:4), modacı (f:3), polis (f:2), eczacı (f:2), mimar (f:2), subay (f:2), futbolcu (f:2), astronot (f:2), bilim adamı (f:1), araba galericisi (f:1), avukat (f:1), mühendis (f:1), 0memur (f:1), jandarma (f:1), hemşire (f:1), müteahhit (f:1), şarkıcı (f:1), ressam (f:1), pilot (f:1), profesör (f:1) olmak istediklerini dile getirmişlerdir. Ayrıca farklı ekonomik düzeye sahip olan çocukların iyi bir üniversiteye gitme, hep başarılı olma, büyük iş kurma planlarının da olduğu saptanmıştır. Bu bulgulara ek olarak, her iki gruptan bir çocuk şuan için gelecekle ilgili planının olmadığını dile getirmiştir.

Okulöncesi Öğretmenliği Anabilim Dalında Okuyan Öğretmen Adaylarının Sokakta Çalışan Çocuklarla Kurdukları Etkileşimler İle İlgili Düşüncelerine İlişkin Bulgular

Tablo 7. Neden bu grup çocuklarla ilgili araştırma yapmayı tercih ettiniz? Sorusuna verilen cevapların dağılımı

\begin{tabular}{lc}
\hline Kategoriler & $\mathrm{f}$ \\
\hline Tanımak/anlamak & 13 \\
Gelecek beklentilerini öğrenmek(hayata bakış açıları) & 5 \\
İlgi Göstermek & 5 \\
Araştırmaların Yetersizliği & 2 \\
\hline
\end{tabular}

Tablo 7 incelendiğinde öğretmen adaylarının sokakta çalışan çocuklarla ilgili çalışma yapmayı tercih etmelerindeki en büyük nedenin bu çocukları Tanımak ve Anlamak (duygu ve düşüncelerini saptamak) olduğu görülmektedir. Bunu takiben sokakta çalışan çocukların Gelecek Beklentilerinin, Hayata Bakış Açılarının nasıl olduğunu öğrenmek, bu çocuklara ilgi göstererek onları önemseyen kişilerin olduğunu hissettirmek ve bu alanda yapılan araştırmaların yetersiz olması öğretmen adaylarının bu çalışmayı tercih etmesinin nedenleri olarak saptanmıștır.

Bu kategorilerin içindeki yanıtlara örnek olarak aşağıdaki ifadeler verilebilir.

K-5 kodlu Öğretmen adayının "Tanımak ve Anlamak" kategorisine ilişkin ifadesi şu şekildedir: "Bizim işimiz çocuklarla olduğu için buna uygun bir konumuz olmalıydı ama aynı zaman da bütün çocukları anlamayı, işimiz dışındaki çocuklara da sevgi ve șefkatle yaklaşmayı öğrenmeli, o çocukları da tanımalıydık o yüzden böyle bir araștırmayı tercih ettik”. K-6 kodlu öğretmen adayının "Tanımak ve Anlamak" kategorisine ve "Gelecek Beklentilerini Öğrenmek" kategorisine ilişkin ifadesi ise şu şekildedir: "O çocukların neler yaşadığını, aslında neler istediklerini ve neler hissettiklerini, mutluluk algılarını, gelecekleriyle ilgili hayallerini öğrenmek istedik. Sokakta çalışmayan ve eğitimlerine devam eden çocuklarla sokakta çalışan çocukların hayatları, düşünce yapıları, gelecek beklentileri, mutluluk algıları arasında ne gibi farklılıklar olabileceğini düşündük ve bu noktadan hareket ettik". K-3 kodlu öğretmen adayının "İlgi Göstermek" kategorisine ilişkin ifadesi şu şekildedir: "Elbette onların hayatlarına sihirli bir değnekle dokunup onların hayatlarını kökünden değiștiremeyiz, ama eğer sorduğumuz sorularla içlerinden birinin bile onların duygularını önemseyen, onları anlamak isteyen insanlarında olduğunu/ olabileceğini fark etmesini sağlayabilirsek ne mutlu bize”. K-2 kodlu öğretmen adayının "Araştırmaların Yetersizliği” kategorisine ilişkin ifadesi şu şekildedir: "Yapılan araştırmaları incelediğimde daha çok sokakta çalışan çocukların sayısının, ne iş yaptıklarının, kökenlerinin ne olduğunun, aile yapılarının nasıl olduğunun araştırıldığını ancak bu çocukların beklentilerinin neler olduğunun sorgulanmadığını gördüm. Benim merak ettiklerim çocukların nereden geldikleri değildi veya ne iş yaptıkları değildi. Bu çocukların mutluluk algılarının ne olduğu, hayattan gelecekten beklentilerinin neler olduğunu, hataya bakış açılarının nasıl olduğunu öğrenmekti".

Tablo 8. Çalışmaya başlamadan önce bu grup çocuklarla ilgili zihninizde ne gibi algılar vardı? Sorusuna verilen cevapların dağılımı

\begin{tabular}{lc}
\hline Kategoriler & f \\
\hline Çocuklardan Zarar Görme & 5 \\
İletişim Kurmaya Yönelik Önyargı & 4 \\
Çocuklara Acıma & 3 \\
Çocukların Zorla Çalıștırılması & 3 \\
Çocukların Israrcı Tavrını Görmezden Gelme & 2 \\
\hline
\end{tabular}


Öğretmen adaylarının bu çocuk grubuyla çalışmayı istemelerine rağmen çalışmaya başlamadan önce bu çocuklara yönelik bazı algllara sahip oldukları belirlenmiştir. Bu algılar söylenme sıklığına göre beş temel kategoriye (onlardan zarar görme, onlarla kurulacak iletişime yönelik önyargılar, çocuklara karşı acıma duygusu, birileri tarafında zorla çalıştırıldıkları düşüncesi ve görmezden gelme, ısrarcı tavırlarından rahatsızlık duyma) ayrılarak değerlendirilmiştir.

Bu kategorilerin içindeki yanıtlara örnek olarak aşağıdaki ifadeler verilebilir.

K-5 kodlu öğretmen adayının "Zarar görme" kategorisine ilişkin ifadesi şu şekildedir: "Gözlemlerim sırasında da çöp toplayan birkaç çocuğun kendi aralarında kuralsız, şımarık ve küfürlü konuşmalarına şahit olunca bu grup çocuklarla konuşmak benim için iyice zorlaşan, çekinmem gerektiğini düşündüğüm bir hal almıştı. Sürekli, çocuklarla konuşmaya kalkarsam sözlü veya fiziksel zararlara maruz kalabilecekmişim gibi hissediyordum. Bu sadece çocuklardan değil onların büyüklerinden de tepki alır mıyım düşüncesiyle birlikte olunca çalışmaya başlamak benim için çok büyük bir sıkıntı sebebi olmuştu. Ciddi ve üzücü olarak o küçük çocuklardan korkmaya başladığımı fark etmiştim". İletişim Kurmaya Yönelik Önyargı kategorisinde bu çocukların adaylarla iletişim kurmak istemeyecekleri düşünülmüştür. K-4 kodlu öğretmen adayının "İletişime Yönelik Önyargılar" kategorisine ilişkin ifadesi şu şekildedir: "Açıkçası çalışmaya başlamadan önce acaba onlarla sağlıklı bir şekilde iletişim kurabilir miyim, ya cevap vermek istemezse, ya da bazı büyük yaş gruplarından sigara ya da başka bir şey isterse gibi kötü düşünceler vardı". Adayların bu çocuklara karşı acıma ve merhamet duygularına sahip oldukları saptanmıştır K-1 kodlu öğretmen adayının "Acıma" kategorisine ilişkin ifadesi şu şekildedir: "Onlara karşı acıma duygusu vardı içimde. Onları ne zaman görsem üzülür, kendimi vicdanen kötü hissederdim". Çocukların Zorla Çalıștırılması kategorisinde ise adayların çocukların zorla çalıştırıldıklarına yönelik algıların olduğu saptanmıştır. K-2 kodlu öğreten adayının "Zorla Çalıştırılma" kategorisine ilişkin ifadesi: "Zihnimde hep ebeveynleri ya da başkaları tarafından zorla çalıştırıldıkları düşüncesi vardı”. "Çocukların Israrcı Tavrını Görmezden Gelme" kategorisinde adayların bu çocukların bir şey satmak için ısrarcı davranışlarından rahatsız oldukları ve bu nedenle bu çocukları görmezden gelme algılarının oluştuğu tespit edilmiştir. K-3 kodlu öğretmen adayının bu kategoriye ilişkin ifadesi şu şekildedir: "Dışarıda dolaşırken bir şeyler satmak için yanıma gelen çocuklardan kimi zaman rahatsız olurdum çünkü çok ısrarcı davranırlardı. Zamanla bu durum bende onları görmezden gelme davranışına veya bir bahaneyle başımdan savuşturmam gerektiği duygusuna yol açmıştır”.

Tablo 9. Bu grup çocuklarla çalışmanın zorluklarının neler olacağını düşünüyordunuz? Sorusuna verilen cevapların dağılımı

\begin{tabular}{ll}
\hline Kategoriler & f \\
\hline Cocukların Yaklaşım Biçimi & 8 \\
Cocukları Çalıștıran Kişilerden Çekinme & 4 \\
Çocuklara Ulaşmada ve Uygulamada Zorluklar & 4 \\
Çocukların Talepkâr Davranışları & 3 \\
\hline
\end{tabular}

Öğretmen adaylarının çalışma öncesinde sokakta çalışan çocuklara yönelik tablo 7'de ortaya koydukları algıları nedeniyle bu grup çocukla çalışmanın bazı açılardan zor olacağına yönelik düşüncelerinin olduğu saptanmıştır. Araştırmada bu grup çocuklarla çalışmanın zorluklarının neler olacağını düşünüyordunuz? Sorusuna karşı 4 temel kategori belirlenmiştir. Öğretmen adaylarının sokakta çalışan çocuklarla görüşmeler yaparken en çok çocukların yaklaşımlarından (çocukların zarar vermesi ve çocukların çekinmesi) zorlanacakları yönünde düşüncelerinin olduğu saptanmıştır. Bunu sırasıyla çocukları çalıştıran kişilerin tavırları, çocuklara ulaşmada ve uygulamada zorluklar ve çocukların talep davranacakları düşüncesi takip etmektedir.

Bu kategorilerin içindeki yanıtlara örnek olarak aşağıdaki ifadeler verilebilir.

K-2 kodlu öğretmen adayının "Çocukların Yaklaşım Biçimi” kategorisine ilişkin ifadesi: "Çocuklara çalıştıkları esnada soruları yönelteceğimiz için soruları cevaplamak istemeyebilirler, bizden çekinip korkabilirler ve görüşme yapmak istemeyebilirler diye düşünüyordum. Kendi açımdan baktığımda da görüșme esnasında bize karşı zarar verici davranıșta bulunurlar mı diye düşünüyordum". K-6 kodlu öğretmen adayının "Çocukları Çalıștıran Kişilerden Çekinme" kategorisine ilişkin ifadesi: "Onları zorla çalıştıran bir yetişkinin onları uzaktan izliyor olabileceği ihtimali vardı. Cocukların yanına yaklaștığımızda yanımıza gelip bizi engellemelerinden veya bize bir zarar vermelerinden çekiniyordum. Böyle bir durumla karşılaşırsam ne yapacağımı bilmiyordum ve bu 
durum beni korkutuyordu". K-3 kodlu öğretmen adayının "Çocuklara Ulaşmada ve Uygulamada Zorluk" kategorisine ilişkin ifadesi: "Bu grup çocuklarla çalışma konusunda onlara ulaşmanın, ulaştığımızda onların formumuzda yer alan sorulara cevap vermek konusunda istekleri olmalarının, istekli olsalar bile soruları anlayıp istediğimiz nitelikte cevap verebilmelerinin zor olacă̆ını düşünüyordum". K-5 kodlu öğretmen adayının "Çocukların Talepkâr Davranışları" kategorisine ilişkin ifadesi: "Sorularımızı yanıtlamanın karşılı̆̆ında bizden para, sigara, yemek gibi isteklerinin olacaklarını düşünüyordum ve bu isteklerin hepsine cevap veremeyeceğimi düşünüyordum".

Tablo 10. Bu grup çocuklarla çalışırken neler hissettiniz? Neler düşündünüz? Sorusuna verilen cevapların dağılımı

$\mathrm{Bu}$ soru 2 boyutta (Öğretmen Adaylarının Gözünden Çocukların Değerlendirilmesi ve Öğretmen Adaylarının Süreçteki Duyuşsal Etkileşimi) incelenmiştir.

(Öğretmen Adaylarının Gözünden Çocukların Değerlendirilmesi)

\begin{tabular}{lc}
\hline Kategoriler & $\mathrm{f}$ \\
\hline Çocukların Tutumu & 12 \\
Çocukların Algılamada Zorlukları & 4 \\
Çocuklar Yaşamda Umutlu & 2 \\
\hline \multicolumn{1}{c}{$\quad$ Öğretmen Adaylarının Süreçteki Duyuşsal Etkileşimi) } \\
\hline \multicolumn{1}{l}{ Kategoriler } & $\mathrm{f}$ \\
\hline Şaşırma & 6 \\
Duygusal Etki & 6 \\
Önyargı ve Korkulardan Uzaklaşma & 3 \\
\hline
\end{tabular}

Öğretmen Adaylarının Gözünden Çocukların Değerlendirilmesi boyutunda üç alt boyut şunlardır: Cocukların Tutumu (çocukların çekingen ürkek davranıșlar sergilediği ancak çalıșmaya karşı istekli, katılımcı davrandıkları saptanmıştır), Çocukların Algılamada Zorlukları ve Cocuklar Yaşamda Umutlu (öğretmen adayları çocukların cevaplarından geleceğe dair umutlu oldukları düşünmektedir).

Bu kategorilerin içindeki yanıtlara örnek olarak aşağıdaki ifadeler verilebilir.

K-2 kodlu öğretmen adayının "Çocukların Tutumu” kategorisine ilişkin ifadesi: "Sorduğum sorular karşısında şaşkın bir yüz ifadesi oldu. Bunun nedeninin bu zamana kadar kimsenin bu çocuklara mutlu oldukları şeylerin neler olduğunu, gelecek beklentilerinin neler olduğunu sorulmadığı için olduğunu düşünüyorum. Yanlarına yaklaşıp bu soruları yönelttiğimde hepsi isteyerek cevapladılar ve yüzlerinde bir gülümseme vardı. Ne kadar insanların ilgilerine, sevgilerine aç olduklarını gördüm. Sorulara cevap verirken bazıları biraz çekingen utangaç davrandı ama yine de sorulara içtenlikle cevaplar verdiler". K-1 Kodlu öğretmen adayının "Çocukların Algılamada Zorlukları" kategorisine ilişkin ifadesi: "Sorularımı sorduktan sonra biraz düşünüp zar zor cevap veren çocuklar da oldu. Hatta bir çocuk cevabı verdikten sonra sürekli kendine güvenmeyip "bu cevap olur mu?" diye tepkilerde bulunuyordu". K-4 kodlu öğretmen adayının "Çocuklar Yaşamda Umutlu” kategorisine ilișkin ifadesi: "Bazılarının gözünde gördüm ki bu çocuklarımız aslında umut taşıyorlar gözleri parlayan çocuklarımız var ve verdikleri cevaplar ile onların toplumumuza kazandırılması gerektiğini gördük. Hayata dair umutlarının olduğunu görmek bizleri de umutlandırdı."

Öğretmen Adaylarının Süreçteki Duyuşsal Etkileşimi'nin Değerlendirilmesi boyutunda üç alt boyut saptanmıştır: Şaşırma (çocukların beklenmedik cevaplar vermesine yönelik şaşkınlık hissetme), Duygusal Etki (Çocukların cevapları karşısında üzüntü acıma vb. duygular), Önyargı ve Korkulardan Uzaklaşma (adaylar bu çocuklara karşı olumsuz önyargılarından kurtulmuştur). Öğretmen adaylarının çocukların verdiği cevaplar karşısında şaşkınlık yaşadıkları, duygusal olarak etkilendikleri, üzüntü yaşadıkları ve çalışmaya başlamadan önceki önyargılarından ve korkularından uzaklaștıkları ortaya çıkmıștır.

Bu kategorilerin içindeki yanıtlara örnek olarak aşağıdaki ifadeler verilebilir.

K-3 kodlu öğretmen adayının "Şaşırma" kategorisine ilişkin ifadesi: "Seni en çok mutlu eden olay, bundan sonra ne olursa çok mutlu olursun sorularına "sevgilim" ile başlayan cevaplar verdiler. Bu duruma çok şaşırdım. 15 yaşındaki kızın beni istemeye gelirlerse çok mutlu olurum cevabı en çarpıcı olanıydı. Bu yaştaki çocukların bu kadar çok sevgililerine düşkün olmaları, hatta evlenmeyi düşünmeleri beni çok ama çok şaşırttı”. K-2 kodlu öğretmen adayının "Duygusal Etki” kategorisine ilişkin ifadesi: 
"Bazı çocukların mutluluk algısının olmaması beni çok etkiledi. Seni mutlu eden olaylar nedir diye sorduğumda mutluluğu algılamayıp nasıl yani diye sorması ve daha sonrada mahalleye taşınmamız gibi cevaplar vermesi beni çok etkiledi. Ayrıca bir yandan bazı çocukların böyle umutlu olmasından dolayı mutlu olurken bir yandan da üzüntü yaşadım. Mutlu olmamım nedeni, hep olumlu düşünmesiydi. Üzüntü yaşamamın nedeni ise bu kadar umutlu bir çocuğun umut ettiklerinin bu şartlar altında gerçekleşemeyecek olmasını düşünmemdi”. K-5 kodlu öğretmen adayının “Önyargı ve Korkulardan Uzaklaşma" kategorisine ilişkin ifadesi: "Yiyip bitiren o korkularımın hepsini yersiz olduğunu anladım. Çalışmaya başlamadan önceki bir diğer algımda çocukların büyükleri tarafindan zarar görebilme ihtimalimizdi. Fakat çalışmaya başladığımda soru sormak istediğim çocukların büyüklerinin de gayet sıcak ve yardımsever davranması bu konuda da kendimi fazla korkuttuğumu anlamama sebep oldu. Çalışmaya başlamadan önce çocukların soruları yanıtlamalarına karşılık benden yemek, sigara, para gibi isteklerinin olacaklarını ve isteklerinin boyutuna göre bunu karșılayamayacağımı düşünüyordum ki aslında bu çocukların karşılıksız yardıma ne kadar açık olduklarını uygulamaya başladıktan sonra gördüm. Benden ek olarak bir şey istemelerini beklerken onlar benim verdiğim küçük hediyeleri bile çekinerek aldılar hatta gerek olmadığını söyleyip, daha çocukla konuşmam gerekirse mahallelerinde çok olduğunu söyleyerek yardıma hazır olduklarını belirttiler".

Tablo 11. Siz olsaydınız, bu grupla yeniden bir çalışma planlamanız gerekseydi nasıl bir çalışma planlardınız?

\begin{tabular}{ll}
\hline Kategoriler & $\mathrm{f}$ \\
\hline $\begin{array}{l}\text { Yaşama Koşulları, Düşünceleri ve İhtiyaçları } \\
\text { Konusunda Derinlemesine Araştırma }\end{array}$ & 4 \\
$\begin{array}{l}\text { Toplumu ve Aileleri SÇÇ Hakkında } \\
\text { Bilinçlendirme/Bilgilendirme Çalışmaları }\end{array}$ & 3 \\
$\begin{array}{l}\text { Eğitimlerini Etkilemeyecek Meslek Edindirme Çalışmaları } \\
\text { Çocukların İhtiyaçlarını Karşılayacak Kurum Açma }\end{array}$ & 2 \\
\hline
\end{tabular}

Araştırmanın bu sorusuna karşılık öğretmen adayları dört farklı kategoriden çalışmalar planlamayı uygun bulmuşlardır. Bu soruya ilişkin bulgular incelendiğinde öğretmen adaylarının en çok sokakta yaşayan çocukların yaşam koşulları, düşünceleri ve ihtiyaçları konusunda derinlemesine araştırmalar yapılmasını düşündükleri ve bunu takiben toplumu ve aileleri sokakta çalışan çocuklar hakkında bilinçlendirme ve bilgilendirme çalışmaları, çocukların eğitimlerini etkilemeyecek meslek edindirme çalışmaları ve çocukların temel ihtiyaçlarını karşılayacak kurum açma yönünde çalışmalar düşündükleri saptanmıştır.

\section{TARTIŞMA VE SONUÇ}

Erken yaşta çalışma yaşamına katılan çocukların kendilerine, yaşamlarına ve geleceğe dair bakış açılarını, mutluluk eşiklerini, aile ilişkilerini, istek, arzu ve hayallerini belirleyebilmek açısından kritik bir öneme sahip olan bu araştırmanın sonuçlarına bakıldığında; çocukların mutluluk algılarına yönelik olarak her iki çocuk grubunda da eğlenceli etkinliklerin (oyun, gezme gibi aktivitelerin) en mutluluk verici eylem olduğu saptanmıștır. Bu sonuç oyun ve eğlencenin hangi statüden, hangi kültürden olursa olsun bütün çocuklar için vazgeçilmez olduğunu göstermektedir. Çalışmada çocuklar, oyun oynamalarını kısıtlayan ya da engelleyen ortamlara rağmen (çalışma mekânları, yoksulluk, yetersiz yaşam koşulları) yaşamlarında oyunu en mutluluk veren eylem olarak dile getirmişlerdir. Bu bulgu Dönmez (1999)' in oyun her çocuğun gerçek yaşantısından daha çok tercih ettiği, daha çok içinde yaşadığı ve mutlu olduğu bir dünyadır görüşünü destekler niteliktedir. Ayrıca diğer dikkat çekici bir bulgu ise çalışmada yer alan çocuklar için aile ile vakit geçirmenin hediye almaktan daha öncelikli ve mutlu edici bir konumda olmasıdır. Çalışmanın bu bulgusu, günümüzün ebeveynlerinin sıklıkla çocuklarını mutlu etmek için öncelikle hediye alma davranışlarını sorgulamamıza neden olmuştur. Çocukları öncelikle mutlu etmenin yolunun asıl ihtiyaç duydukları yakın, doyurucu bir birliktelik içerisinde olma olduğu çocuklar tarafından dile getirilmiştir. Nitekim Büyükkucak (2014) çocuklara alınan değerli hediyeler ve oyuncaklardansa onlarla geçirilen nitelikli zamanların kat kat daha kıymetli olduğunu açıklamıştır. 
Çalışmada yer alan sokakta çalışan çocukların gelecekte mutlu olmak adına beklenti ve isteklerine bakıldığında okula yönelik özlemleri olduğu saptanmıştır. Çocukların olumsuz yaşam koşulları onları çalışmaya itmekle kalmayıp eğitim alma haklarını da ellerinden alarak geleceklerinin önünde çok büyük bir engel olarak rol oynamaktadır. Nitekim Çalık ve Kara (2012) araştırmalarında, çocukların çalışmalarındaki en büyük nedenin yoksulluk olduğunu saptamışlar ve bu çocukların maddi olanaklarının düzenlenmesi durumunda çalışmak zorunda kalmayacaklarını ortaya koymuşlardır. Bu çocuklar okula gitmek yerine dört yol ağzında mendil satmak, küçücük bedenleri ile arabalarının önüne atlayarak cam silmeye çalışmak, elindeki sakızı satabilmek için insanların peşinden koşmak zorunda bırakılıyor. Nitekim bu kapsamda çalışmada yer alan sokakta çalışan çocukların okula gitmek ve ders çalışma isteklerini farklı ekonomik düzeye sahip olan çocuklardan daha fazla dile getirdikleri görülmüştür. Kulaksız (2014)' a göre çocukların çalışma hayatı içerisinde olmaları, okuldan tamamen kopmalarına ya da iş ile okulu birlikte yürütmelerine neden olmaktadır. Ancak her iki durumda da çocukların eğitimden uzak kaldıklarını dile getirmektedir. Bu çalışmada elde edilen bulguda da çocukların çalıştıkları için okula gidemedikleri ve okula gidenlerin de işlerinden dolayı derslerine çalışamadıkları ortaya konmuştur.

Çalıșmada yer alan çocukların kendilerinde var olduğu düșündükleri yeteneklere ilișkin bulgular incelendiğinde farklı ekonomik düzeye sahip olan çocukların sokakta çalışan çocuklara nazaran yeteneklerinin daha çok farkında oldukları ve bunları daha çok dile getirdikleri görülmüştür. Sokakta çalışan çocukların hobi olarak nitelendirilen çok az sayıda yetenekleri olduğu saptanırken, diğer çocuk grubunun ise bu alanda yeteneklerinin daha fazla olduğu saptanmıştır. Sokakta çalışan çocukların omuzlarındaki yükler sadece çocukluklarını doyasıya yaşamalarına engel olmamaktadır aynı zamanda kendilerini geliştirmelerine, farklı alanlarda beceriler edinmelerine de engelleyici olmaktadır. Nitekim Çalık ve Kara (2012) yaptıkları çalışmada da sokakta çalışan çocukların tamamının herhangi bir hobisinin olmadığını saptamışlardır ve bu çocukların eğitim eksiklikleri ile birlikte kültürel ve aktivite açısından da eksikliklerinin olduğunu ifade etmișlerdir.

Araştırmanın en umut verici bulgusu ise çocukların geleceğe yönelik planlarına ilişkin ifadeleri olmuştur. Sokakta çalışan çocukların yaşamlarındaki tüm travmalara, yoksulluklara, hatta okula hiç gidememe veya kayıtlı olsa dahi eğitimi takip edememeye rağmen farklı ekonomik düzeye sahip olan akranları gibi geleceğe umutla baktıkları nitelikli meslekler hayal ettikleri gözlenmiștir. Bu araştırmanın bulgusu ile paralellik gösteren Şişman (2006)' in yaptığ çalışmada sokakta çalışan çocukların büyük bir bölümünün doktor, avukat vb. profesyonel bir meslek sahibi olmayı hayal ettikleri saptanmıştır.

Sonuç olarak sokakta çalışan çocuklar her çocuk gibi hiçbir ayrıcalık gözetilmeksizin temel haklar konusunda gereksinimlerini ve gelecek beklentilerini dile getirmişlerdir. Bunlar;

Eşit olanaklar temeline dayanan bir eğitim,

En temel olağan yaşam koşullarına sahip olma (kendine ait bir yatak, çalışma odası gibi)

Aile içi sorunların çözümüne yönelik istekler,

Kendi becerilerini geliştirebilmelerini sağlayacak ortamlar

Meslek edinme beklentilerini gerçekleștirmelerini sağlayacak olanaklardır.

$\mathrm{Bu}$ çalışmanın ikinci boyutu olan okul öncesi öğretmenliğinde okuyan öğretmen adaylarının sokakta çalışan çocuklarla gerçekleştirdikleri görüşmeler sonucunda söz konusu çocuklara yönelik bakış açllarında önemli değişiklikler gözlediklerini dile getirmişlerdir. Öğretmen adaylarının çalışmaya başlamadan önce sokakta çalışan çocuklara yönelik önyargıları, onlardan zarar görmeye yönelik korkuları varken çalışma sonunda çocukların sevecen ve sıcak yaklaşımları ile bu önyargı ve korkularından uzaklaşarak çocuklara yönelik olumlu algılar geliştirmeye başlamaları oldukça düşündürücü bir gelişmedir. Bu çocukları görmezden gelmek yerine sadece etkileşime geçmenin bile önyargılarımızı iyileştirici bir işleve sahip olduğu görülmektedir.

Bu sonuçlar doğrultusunda;

En kritik noktanın öncelikle onları fark etmek, gereksinimlerini duymaya, çözüm bulmaya açık olmak ve etkileșim/ iletişim kurmanın gücüne inanmak,

Sokakta çalışan çocukların yaşam koşullarının iyileştirilmesine yönelik çalışmalar planlamak (barınma, sağlık, eğitim ve iş olanakları), sunmak,

Çocuklara yeteneklerini ortaya çıkaracak ve kendilerini geliştirmelerini sağlayacak aktiviteler 
Toplumun sokakta çalışan çocuklara yönelik bilinçlendirilmesi ve bu çocuklara karşı olan önyargılardan arınmalarına yönelik çalışmalar yapmak,

Ve en önemlisi eğitim, çocuk iş̧̧iliğini sona erdirecek en önemli ve etkin araçtır. Bu çocuklar için temel eğitim ve mesleki eğitimin yaygınlaştırılması konusunda çalışmalar yapmak gerekmektedir.

\section{KAYNAKÇA}

Alparslan, Ö. ve Karaoğlan, B. (2012). Sokakta çalışan çocukların yaşam koşulları. Anadolu Hemşirelik ve Sağllk Bilimleri Dergisi, 15(4), 268-274.

Alparslan, Ö. (2012). Sokakta çalışan çocukların yaşam koşulları. Anadolu Hemşirelik ve Sağlık Bilimleri Dergisi. Arnas, A. Y. (2003). Sokak çocukları. Toplum ve Sosyal Hizmet, 14(2). 43-58.

Aysev, A., Ulukol, B., ve Ceyhun, G. (2000). Çalışan ve okuyan çocukların "çocuklar için depresyon ölçeği" ile değerlendirilmesi. Ankara Üniversitesi Tıp Fakültesi Mecmuası, 53(1), 27-30.

Bademci, Ö. (2013). Merkez'in çocukları: istanbul sokaklarında çalışan çocukların bakış açısı ile sokaklar. C..Ü. Sosyal Bilimler Enstitüsü Dergisi, 22(1), 323-336.

Başal, H. A., Derman, T. M., ve Peymi, P. (2010). Sokakta çalıştırılan çocukların benlik saygısı, denetim odağı ve umutsuzluk düzeyleri. e-Journal of New World Sciences Academy Education Sciences, 5(1), 89-106.

Bilgin, R. (2012). Sokakta çalışan çocukları bekleyen risk ve tehlikeler: Diyarbakır örneği. ZKÜ Sosyal Bilimler Dergisi, 8(15), 80-96.

Bilgin, R. (2009). Diyarbakırda sokakta çalışan çocuklar üzerine sosyolojik bir araştırma. Elektronik Sosyal Bilimler Dergisi, 8(27), 232-244.

Büyüköztürk, Ş., Çakmak, E. K., Akgün, Ö. E., Karadeniz, Ş. ve Demirel, F. (2011). Bilimsel araştırma yöntemleri. Ankara: Pegem Yayıncllık.

Büyükkucak, M. (2014). Hediyeleri değil, birlikte geçirdiğiniz zamanı hatırlarlar!. http://www.milliyet.com.tr/hediyeleri-degil--birlikte-pembenar-detay-cocuk-1622854/ (Ekim 2016 tarihinde internetten alınmıştır).

Christensen, L. B., Johnson, R. B. \& Turner, L. A. (2015). Araştırma yöntemleri desen ve analiz. (Çev. Ed. Ahmet Aypay). Ankara: Anı Yayıncllı.

Dönmez, N. B. (1999). Üniversite çocuk gelişimi ve eğitimi bölümü ve kız meslek lisesi öğrencileri için oyun kitabı. İstanbul: Esin Yayınevi.

Esenay, F. I., Öncü, E., Kurt, A. Ö. ve Özer, F. (2012). Çalışan çocukların ailede istismarı. Türkiye Halk Sağliğı Dergisi, 10(3), 128-140.

Erdoğdu, Y. M. ve Oto, R. (2004). Sokakta çalışan ve çalışmayan çocukların atılganlık ve saldırganlık davranışları açısından karşılaştırılması. Kiraz Dergisi, 12(3), 11-23.

Güngör, M. (2008). Evrensel bir sorun olarak çocuk suçluluğu ve sokakta çalışan ve yaşayan çocuklar. Adıyaman Üniversitesi Sosyal Bilimler Enstitüsü Dergisi, 1(1), 25-43.

Kağıtçıbaşı, C.. (2012). Benlik aile ve insan gelişimi (3. Baskı). İstanbul: Koç Üniversitesi Yayınları.

Kara, B. K. ve Çalık, T. (2012). Sokakta çalışan çocukların eğitim ihtiyaçları. GEFAD/GUJGEF, 32(3), 673-695.

Konanç, E. (1992). Korunmaya muhtaç kent çocukları. Friedrich Ebert Vakfi Yayınları, İstanbul.

Kulaksız, Y. (2014). Yoksulluk bağlamında çocuk işgücü. Çalışma Dünyası Dergisi, 2(3), 91-111.

Perry, B. D. V. ve Szalavitz, M. (2012). Köpek gibi büyütülmüş çocuk (7. Baskı). İstanbul: Okyanus Yayın.

Şişman, Y. (2006). Sokakta çalışan çocukların yaşam koşulları ve gelecek beklentileri. Sosyal Bilimler Dergisi, 2, 251-276.

Şimşek, Z. ve Erol, N. (2003). Çalışan çocuklarda yeterlik alanları davranışsal ve duygusal sorunlar. Toplum ve Sosyal Hizmet, 14(2), 59-70.

Tor, H. (2010). Türkiye'de çocuk işçiliğinin boyutları. Zeitschrift für die Welt der Türken/Journal of World of Turks, 2(2), 25-42.

UNICEF, (2004). Çocuk haklarına dair sözleşme: birinci kısım, madde 1-20. http://www.unicef.org/turkey/crc/cr23c.html (Mart 2016 tarihinde internetten indirilmiştir).

Yetim, N. ve Çağlayandereli, M. (2007). Toplumsal algı boyutuyla sokakta çalışan çocuklar: Mersin örneği. Sosyoloji Dergisi, 3(14), 32-55.

Yıldız, Ö. (2007). Sokakta çalışan çocuklar: Sorun mu? Çözüm mü?. Gaziantep Üniversitesi Sosyal Bilimler Dergisi, 6(2), 134-143.

Yıldırım, A. ve Şimşek, H. (2013). Sosyal bilimlerde nitel araştırma yöntemleri (9. Baskı). Ankara: Seçkin Yayıncllık.

Yürük, R. ve Yalçın, E. (2008). Çocuklar neden sokağa iniyor?. http://www.ilkehaberajansi.com.tr/haber/cocuklar-neden-sokaga-iniyor.html (Mart 2016 tarihinde internetten alınmıştır). 